\title{
Effects of neuropeptides $B$ and $W$ on the rat pituitary-adrenocortical axis: In vivo and in vitro studies
}

\author{
ANNA HOCHOL ${ }^{1}$, CINZIA TORTORELLA ${ }^{2}$, MARCIN RUCINSKI ${ }^{1}$, AGNIESZKA ZIOLKOWSKA ${ }^{1}$, \\ GASTONE G. NUSSDORFER ${ }^{2}$ and LUDWIK K. MALENDOWICZ ${ }^{1}$ \\ ${ }^{1}$ Department of Histology and Embryology, Poznan School of Medicine, PL-60781 Poznan, Poland; \\ ${ }^{2}$ Department of Human Anatomy and Physiology (Section of Anatomy), University of Padua, I-35121 Padua, Italy
}

Received September 6, 2006; Accepted October 24, 2006

\begin{abstract}
Neuropeptides (NP) B and W are hypothalamic peptides involved in the regulation of feeding and neuroendocrine axes. Evidence has been provided that NPB and NPW act on both the central and the peripheral branches of the rat hypothalamic-pituitary-adrenocortical axis, and we carried out in vivo and in vitro studies to gain insight into this topic. Reverse transcription-polymerase chain reaction showed the expression of NPB, NPW and their receptors in both adrenal cortex (zonae glomerulosa and fasciculata-reticularis) and adrenal medulla, where immunocytochemistry also detected the presence of abundant NPB- and NPW-immunoreactivity. The acute subcutaneous administration of NPB ( 0.5 or $1.5 \mathrm{nmol} / 100 \mathrm{~g}$ ) did not alter ACTH plasma concentration, while that of NPW $(1.5 \mathrm{nmol} / 100 \mathrm{~g})$ decreased it. Neither NPB nor NPW affected the blood level of aldosterone, while both peptides $(0.5 \mathrm{nmol} / 100 \mathrm{~g})$ raised that of corticosterone. NPB $\left(10^{-6} \mathrm{M}\right)$ lowered ACTH-stimulated aldosterone secretion, and basal and ACTH-stimulated corticosterone production from adrenal quarters containing both cortical and medullary tissues. NPW $\left(10^{-6} \mathrm{M}\right)$ enhanced basal aldosterone secretion from adrenal quarters, and the effect was suppressed by the $\beta$-adrenoceptor antagonist $l$-alprenolol $\left(10^{-5} \mathrm{M}\right)$. NPW did not affect corticosterone production. Collectively, our findings allow us to draw the following tentative conclusions: i) ACTHindependent extra-adrenal mechanism(s) are operative in vivo, by which NPB and NPW stimulate adrenal glucocorticoid, but not mineralocorticoid secretion; ii) in vitro the interaction of NPB with adrenal medulla activates unknown mechanism(s) hampering adrenocortical steroidogenic machinery; and iii) NPW stimulates in vitro aldosterone secretion by enhancing the release of medullary catecholamines, which in turn activate ß-adrenoceptors located on zona glomerulosa cells.
\end{abstract}

Correspondence to: Professor G.G. Nussdorfer, Department of Human Anatomy and Physiology, Section of Anatomy, Via Gabelli 65, I-35121 Padua, Italy

E-mail: gastone.nusdorfer@unipd.it

Key words: neuropeptide B, neuropeptide W, GPR7, GPR8-like receptor, pituitary-adrenocortical axis, rat

\section{Introduction}

In the course of studies, aimed at discovering new $G$ proteincoupled receptors (GPR), two highly homologous genes were identified and named GPR7 and GPR8, whose sequence is similar to that of somatostatin- and opioid-receptor genes (1). However, GPR7 and GPR8 do not bind somatostatin, and only GRP7 displays low affinity for nonselective opioid ligands. GPR8 is absent in rodents, where it is replaced by the GPR8like receptor (GPR8-LR) $(1,2)$. Subsequent investigations led to the discovery of two endogenous ligands of GPR7 and GPR8 (3-6): one of them, a 29-amino acid peptide, is brominated, and hence was named neuropeptide (NP)B; the other ligand, called NPW, was identified into two molecular forms, NPW30 and NPW23, with NPW23 being identical to the N-terminal 23 amino-acid sequence of NPW30.

Several findings indicate that NPB, NPW and their receptors are involved in the central regulation of energy homeostasis and feeding behavior (7-10). However, there is also evidence that NPB and NPW may also regulate neuroendocrine functions in the rat, and in particular that of the hypothalamic-pituitary-adrenocortical (HPA) axis, the central branch of which they stimulate, acting as potential stress mediators (9,11-13). Proof is also available that NPB and NPW are able to directly activate the peripheral branch of the HPA, acting via GPR7 and GPR8/GPR8-LR located on adrenocortical cells (14-16).

The aim of this study was to investigate the expression of NPB, NPW and their receptors in the various zones of the rat adrenal gland, and to examine the in vivo and in vitro effects of these neuropeptides on the pituitary-adrenocortical axis.

\section{Materials and methods}

Animals and reagents. Adult female Wistar rats ( 120 g body weight), bred in our laboratory facilities, were kept under a $14 / 10 \mathrm{~h}$ light/dark cycle at $23^{\circ} \mathrm{C}$, and maintained on a standard diet and tap water ad libitum. The study protocol was approved by the local Ethics Committee for Biomedical Studies. Rat NPB29 and NPW23, and rabbit anti-NPB29 and anti-NPW23 primary antibodies were purchased from Phoenix Pharmaceuticals (Belmont, CA), and normal goat serum and Strept AB complex/HRP secondary antibodies from Dako (Glostrup, Denmark). ACTH, $l$-alprenolol, bovine serum albumin (BSA), 
phosphate-buffered saline (PBS), and all other chemicals and laboratory reagents were provided by Sigma-Aldrich Corp. (St. Louis, MO).

Experimental design. Groups of rats were decapitated, and their adrenal glands were promptly removed. Specimens were immediately placed in RNA later (Qiagen, Hilden, Germany) or fixed in Bouin's solution for immunocytochemistry (ICC). For reverse transcription (RT)-polymerase chain reaction (PCR) studies some adrenals were dissected into capsulezona glomerulosa $(\mathrm{ZG})$, inner zonae fasciculata-reticularis (ZF/R) and adrenal medulla (AM) (17). Other adrenal glands were quartered, placed in PBS and immediately used for functional in vitro studies. Quarters were preincubated for $30 \mathrm{~min}$ at $37^{\circ} \mathrm{C}$ in $1 \mathrm{ml} \mathrm{Krebs-Ringer} \mathrm{bicarbonate} \mathrm{buffer} \mathrm{with}$ $0.3 \%$ glucose (KRBG). The medium was discarded and quarters were put in fresh KRBG added with $0.3 \%$ BSA, in which the following substances were dissolved: i) NPB or NPW (10 $\left.10^{-6} \mathrm{M}\right)$; and ii) ACTH $\left(10^{-8} \mathrm{M}\right)$ or $l$-alprenolol $\left(10^{-5} \mathrm{M}\right)$ alone and in the presence of NPB or NPW $\left(10^{-6} \mathrm{M}\right)$. Control quarters were incubated in the absence of any chemical. The incubation was carried out in a shaking bath at $37^{\circ} \mathrm{C}$ for $120 \mathrm{~min}$, in an atmosphere of $95 \%$ air- $5 \% \mathrm{CO}_{2}$ (18). Medium was collected and stored at $-36^{\circ} \mathrm{C}$ until radioimmune assay (RIA). Groups of rats were given daily subcutaneous (s.c.) injections of $0.2 \mathrm{ml} 0.9 \% \mathrm{NaCl}$ for 9 days to dampen injectionand handling stress (19). At day 10 (time 0), rats received a s.c. injection of 0.5 or $1.5 \mathrm{nmol} / 100 \mathrm{~g}$ of NPB or NPW, and were decapitated $30 \mathrm{~min}$ later. The trunk blood was collected in the presence of EDTA $(1 \mathrm{mg} / \mathrm{ml})$, and plasma was separated and stored at $-36^{\circ} \mathrm{C}$ until RIA.

$R T-P C R$. Total RNA was extracted from adrenal specimens, and reverse transcribed to cDNA $(15,17,20)$. PCR was performed in a Perkin-Elmer 480 DNA thermal cycler (PerkinElmer Life Sciences, Milan, Italy) (21-23), using the primers and the amplification program previously described (13). To rule out the possibility of amplifying genomic DNA, one PCR was carried out without prior RT of the RNA. Detection of the PCR amplification products was done by size fractionation on $2 \%$ agarose gel electrophoresis. The specificity of the PCR was further verified by sequencing analysis (24).

ICC. Bouin-fixed adrenals were processed for ICC as detailed earlier $(25,26)$. Sections were incubated with the primary antibodies (1:200 dilution) for $60 \mathrm{~min}$ at $4^{\circ} \mathrm{C}$, and then after 10-min washing in PBS, with the secondary antibody (1:100 dilution) for $60 \mathrm{~min}$ at $37^{\circ} \mathrm{C}$. The peroxidase activity was detected using the Dako liquid DAB substrate-chromogen system (Dako), and, when necessary, nuclei were counterstained with hematoxylin. Negative controls were carried out by similarly treating adjacent sections and omitting the primary antibody, as well as using primary antibodies preabsorbed with antigen excess.

RIA. ACTH was extracted from plasma, and its concentration was measured by the ACTH double antibody RIA kit (Diagnostic Products Corp., Los Angeles, CA). Sensitivity, $8 \mathrm{pg} / \mathrm{ml}$; intra- and interassay CVs, 6 and 9\%, respectively. Aldosterone and corticosterone were extracted from plasma

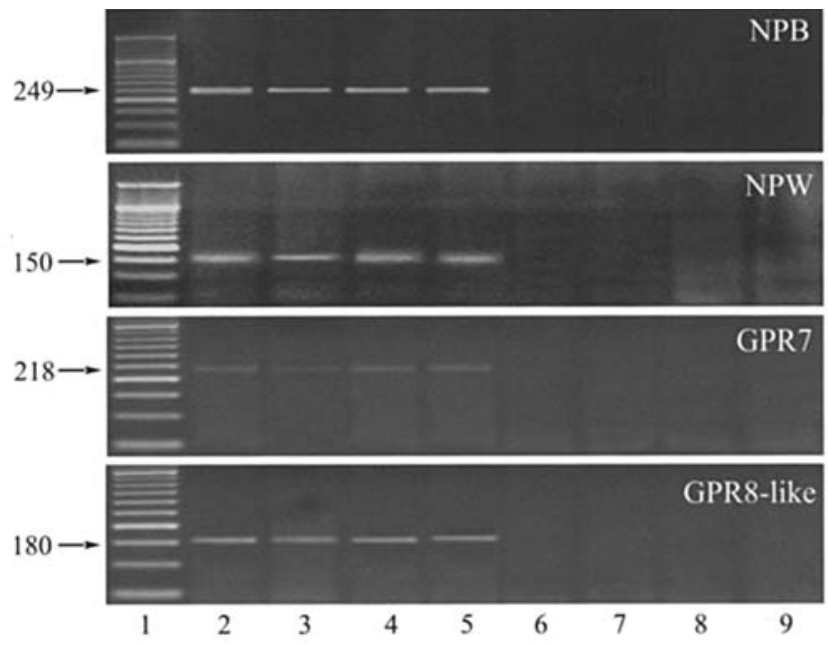

Figure 1. Ethidium bromide-stained $2 \%$ agarose gel showing cDNA amplified with rat ppNPB-, ppNPW-, GPR7- and GPR8-LR-specific primers from exemplary rat adrenal cortex (lane 2), ZG (lane 3), ZF/R (lane 4) and AM (lane 5). Respective negative controls (no RT of the mRNA) are shown in lanes 6-9. Lane 1 was loaded with $200 \mathrm{ng}$ of a DNA size marker (50 bp DNA Ladder; MBI Fermentas, Vilnius, Lithuania).

and incubation media, and their concentrations were determined by RIA, as previously detailed (27). Aldosterone-RIA: sensitivity, $5 \mathrm{pg} / \mathrm{ml}$; intra- and interassay $\mathrm{CVs}, 5$ and $7 \%$, respectively. Corticosterone-RIA: sensitivity, $50 \mathrm{pg} / \mathrm{ml}$; intraand interassay CVs, 7 and 9\%, respectively.

Statistics. Data were expressed as means \pm SEM of the number of independent experiments indicated in the figure legends, and their statistical comparison was done by ANOVA, followed by the multiple range test of Duncan.

\section{Results}

RT-PCR revealed the expression of prepro(pp) NPB, ppNPW, GPR7 and GPR8-LR mRNAs in the rat ZG, ZF/R and AM (Fig. 1). As expected (13), ICC showed the presence of NPBand NPW-immunoreactivity (IR) in both adrenal cortex and medulla. In medullary chromaffin cells immunostaining was mainly located in the perinuclear region, and in the case of NPW the reaction was observed also in ganglion and SIF (small intensive fluorescent) serotonin-positive extraganglionic cells (Fig. 2).

The acute administration of NPB did not alter plasma ACTH concentration, while that of NPW (at the higher dose) significantly decreased it. Neither NPB nor NPW affected the blood level of aldosterone, while the administration of the lower dose of both peptides evoked a marked rise in the blood concentration of corticosterone (Fig. 3).

NPB decreased ACTH-stimulated aldosterone secretion from adrenal quarters, without affecting the basal one, and significantly lowered both basal and ACTH-stimulated corticosterone production (Fig. 4, upper panels). In contrast, NPW enhanced basal aldosterone secretion, without changing either the ACTH-stimulated one or corticosterone secretion (Fig. 4, lower panels). $l$-Alprenolol per se did not affect aldosterone secretion, and exerted doubtful effects on corticosterone production: inhibitory action in the NPB-group and no effect in the NPW-group (Fig. 4, right panels). The 

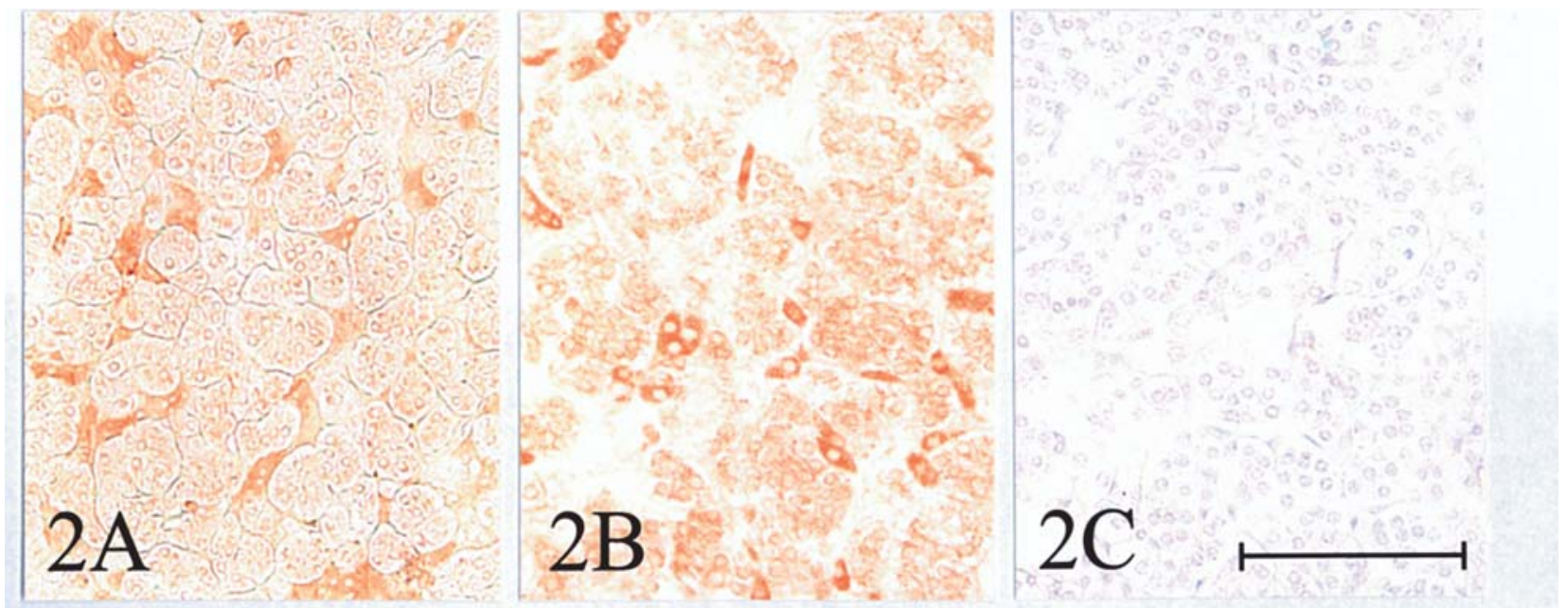

Figure 2. ICC localization of NPB-IR (A) and NPW-IR (B) in the rat AM. Negative control (C) was obtained by omission of the primary antibody. Magnification as defined by bar, $100 \mu \mathrm{m}$.

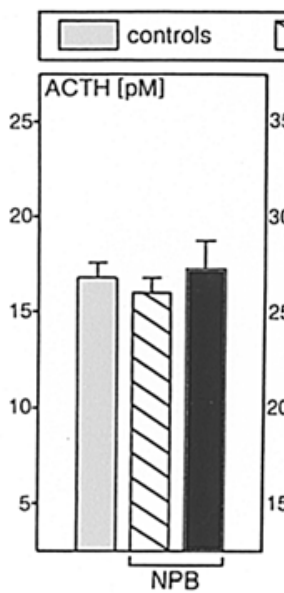

$0.5 \mathrm{nmol} / 100 \mathrm{~g}$

$\square 1.5 \mathrm{nmol} / 100 \mathrm{~g}$
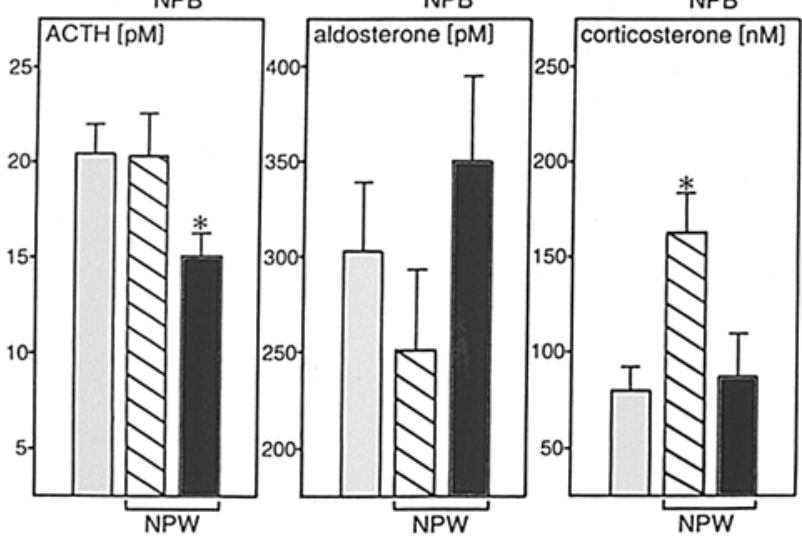

Figure 3. In vivo acute effect of NPB (upper panels) and NPW (lower panels) on the rat plasma concentrations of $\mathrm{ACTH}$, aldosterone and corticosterone. Bars are means $\pm \operatorname{SEM}(n=6) .{ }^{*} \mathrm{P}<0.05$ from control group.

only appreciable effect of $l$-alprenolol was the suppression of the NPW-induced basal rise in aldosterone secretion (Fig. 4, right lower panel).

\section{Discussion}

Our present findings indicate that NPB, NPW and their receptor genes are expressed in the rat adrenals, thereby
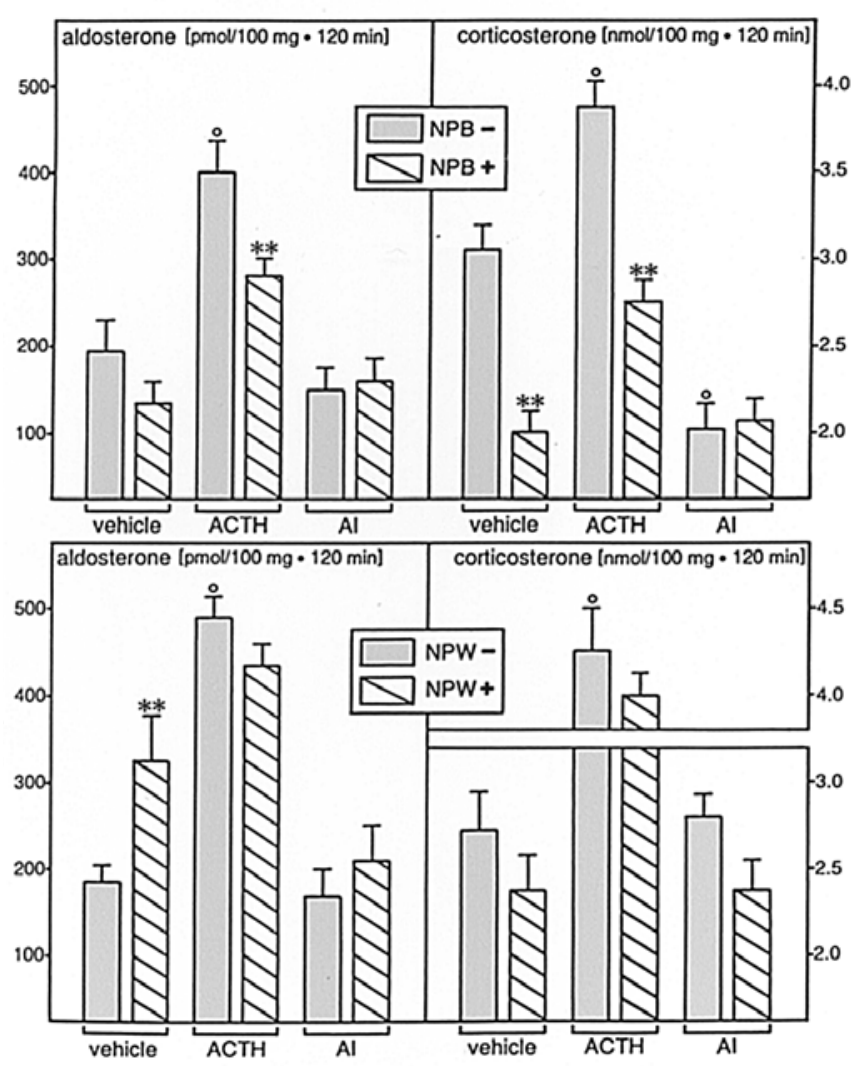

Figure 4. Effects of NPB (upper panels) and NPW (lower panels), alone or in the presence of ACTH and $l$-alprenolol (AL), on aldosterone and corticosterone secretion from AM-containing adrenal quarters. Bars are means \pm SEM $(n=8) .{ }^{* *} \mathrm{P}<0.01$ from the respective NPB- or NPW-groups; ${ }^{\circ} \mathrm{P}<0.01$ from the respective vehicle group.

confirming earlier observations $(13,14)$. They also provide the first demonstration that the expression of these genes occurs in both the cortex ( $\mathrm{ZG}$ and $\mathrm{ZF} / \mathrm{R}$ ) and $\mathrm{AM}$ of the rat adrenals.

As pointed out in the Introduction, both NPB and NPW are thought to be implicated in the regulation of the HPA axis. Although the intracerebroventicular (icv) administration of 
NPW was not found to change the blood level of ACTH in rats $(4,11)$, it has been reported to evoke a marked rise in the $c$-Fos expression in the paraventricular nucleus $(10,12)$ and to increase the plasma concentration of corticosterone (11). The icv injection of NPB has been shown to enhance corticosterone, but not ACTH, blood level (9). We recently showed that the s.c. injection of $2 \mathrm{nmol} / 100 \mathrm{~g}$ of NPW, but not NPB, evoked within 60 min a marked rise in the ACTH blood concentration (13). Our present findings are in partial disagreement with these previous ones, because they indicate that the injection of a lower dose $(1.5 \mathrm{nmol} / 100 \mathrm{~g})$ of NPW caused within 30 min a marked decrease in the ACTH plasma concentration, and at present we are unable to provide a plausible explanation for this descrepancy. Be that as it may, according to earlier observations $(9,11,13)$, both neuropeptides were found to increase the plasma level of corticosterone within $30 \mathrm{~min}$, without apparently affecting that of aldosterone.

Collectively, the above described findings stress that the neuropeptide-induced changes in the blood level of ACTH are not paralleled in vivo by changes in the plasma concentrations of aldosterone and corticosterone, the secretion of which is known to be under ACTH control. This strongly suggests that both NPB and NPW may directly influence adrenocortical cell secretion, which is in keeping with the present demonstration that both $\mathrm{ZG}$ and $\mathrm{ZF} / \mathrm{R}$ cells express GPR7 and GPR8-LR. Previous studies demonstrated a direct effect in vitro of NPB and NPW on adrenocortical cells, but the results were rather conflicting depending on the species and the technique used (14-16). To summarize, NPB and NPW i) did not affect basal aldosterone secretion from freshly dispersed rat and human ZG cells; ii) did not change basal corticosterone secretion from dispersed rat $\mathrm{ZF} / \mathrm{R}$ cells, but enhanced cortisol production from dispersed human $\mathrm{ZF} / \mathrm{R}$ cells, through the activation of the adenylate cyclase- and phospholipase C-dependent cascades; and iii) raised corticosterone production from cultured rat $\mathrm{ZF} / \mathrm{R}$ cells, but not cortisol release from human adrenocortical carcinoma-derived NCIH295 cells.

To gain insight into the possible direct effects of NPB and NPW on adrenocortical cells, we carried out in vitro experiments using AM-containg adrenal quarters. The rationale of such an in vitro approach is: i) in adrenal quarters the structural interrelationships between cortex and medulla are preserved, which is very important because the functional interactions between adrenocortical and medullary chromaffin cells are well documented (reviewed in ref. 28): catecholamines are able to stimulate steroidogenesis, adrenocortical cells (and especially ZG cells) being provided with $ß$-adrenoceptors. Several regulatory peptides have been shown to enhance steroid secretion by eliciting the release from chromaffin cells of catecholamines, that in turn stimulate adrenocortical cells acting in a paracrine manner: VIP and PACAP, neuropeptide-Y, tachykinins, endothelins, adrenomedullin (reviewed in refs. 29-33), cerebellin (34,35) and ANP (36); and ii) the present investigation shows that rat medullary chromaffin cells express GPR7, GPR8-LR and their ligands, thereby strongly suggesting a possible effect of NPB and NPW on catecholamine release. Unfortunately, our in vitro findings raised a number of intriguing issues, more than clarifying the mechanism(s) underlying the direct effects of NPB and NPW on adrenocortical cells.

NPB was found to exert an antisecretagogue action on adrenocortical slices. This observation does not fit either with the results obtained using dispersed adrenocortical cells, where NPB increased ACTH-stimulated aldosterone secretion without changing the corticosterone one (14), or with the present in vivo findings indicating that these peptides raised the level of circulating corticosterone. We tentatively conclude that i) the interactions of NPB with AM activate unknown mechanism(s) inhibiting adrenocortical steroidogenic machinery; and ii) in vivo ACTH-independent extra-adrenal mechanism(s) are operative, by which NPB enhances glucocorticoid, but not mineralocorticoid, secretion. Such latter mechanism(s) could also be involved in the in vivo glucocorticoid secretagogue action of NPW, which in vitro is unable to affect corticosterone production from either dispersed adrenocortical cells (14) or adrenal quarters. Conversely, NPW enhances aldosterone secretion from adrenal quarters, but not from dispersed cells (14). The hypothesis is advanced that this aldosterone secretagogue action of NPW may be mediated be the enhanced release of medullary catecholamines, and the following pieces of evidence support this contention: i) the effect was abrogated by the specific $\beta_{1}$-adrenoceptor antagonis $l$-alprenolol (28); and ii) $l$-alprenolol did not alter per se basal aldosterone secretion, thereby ruling out the possibility that the effect of this antagonist was due to a nonspecific inhibitory effect on the ZG steroidogenic pathways.

NPB and NPW bind and activate both their receptors (Introduction), but with opposite affinities: NPB, GPR7 > GPR8/GPR8-LR; and NPW, GPR8/GPR8-LR > GPR7 $(5,6)$. On these grounds and in light of the present findings, we tentatively propose that: i) the extra-adrenal mechanism(s) underlying the in vivo glucocorticoid secretagogue effect of NPB and NPW are mediated by both GPR7 and GPR8-LR; and ii) GPR7 and GPR8-LR activation mediates the adrenomedullary mechanism(s) involved in the in vitro inhibition of glucocorticoid release and stimulation of aldosterone secretion, respectively. Further studies carried out using the selective immuno-blockade of GPR7 and GPR8-LR are underway to address this issue.

\section{Acknowledgements}

We are indebted to Miss A. Coi for outstanding secretarial support and help in the search and delivery of bibliographic items. This work is a part of the Ph.D. thesis of A. Hochol submitted to the Poznan School of Medicine.

\section{References}

1. O'Dowd, Scheideler MA, Nguyen T, Cheng R, Rasmussen JS, Marchese A, Zastawny R, Heng HH, Tsui LC, Shi X, Asa S, Puy L and George SR: The cloning and chromosomal mapping of two novel human opioid-somatostatin-like receptor genes, $G P R 7$ and GPR8, expressed in discrete areas of the brain. Genomics 28: 84-91, 1995.

2. Lee DK, Nguyen T, Porter CA, Cheng R, George SR, Brian F and O'Dowd BF: Two related G protein-coupled receptors. The distribution of GPR7 in rat brain and the absence of GPR8 in rodents. Mol Brain Res 71: 96-103, 1999. 
3. Fujii R, Yoshida H, Fukusumi S, Habata Y, Hosoya M, Kawamata Y, Yano T, Hinuma S, Kitada C, Asami T, Mori M, Fujisawa $\mathrm{Y}$ and Fujino $\mathrm{M}$ : Identification of a neuropeptide modified with bromine as an endogenous ligand for GPR7. J Biol Chem 277: 34010-34016, 2002.

4. Shimomura Y, Harada M, Goto M, Sugo T, Matsumoto Y, Abe M, Watanabe T, Asami T, Kitada C, Mori M, Onda H and Fujino M: Identification of neuropeptide $\mathrm{W}$ as the endogenous ligand for orphan $\mathrm{G}$ protein-coupled receptors GPR7 and GPR8 J Biol Chem 277: 35826-35832, 2002.

5. Brezillon S, Lannoy V, Franssen JD, Le Poul E, Dupriez V, Lucchetti J, Detheux $M$ and Parmentier M: Identification of natural ligands for the orphan $G$ protein-coupled receptors GPR7 and GPR8. J Biol Chem 278: 776-783, 2003.

6. Tanaka H, Yoshida T, Miyamoto N, Motoike T, Kurosu H, Shibata K, Yamanaka A, Williams SC, Richardson JA, Tsujino N, Garry MG, Lerner MR, King DS, O'Dowd BF, Sakurai T and Yanagisawa M: Characterization of a family of endogenous neuropeptide ligands for the $G$ protein-coupled receptors GPR7 and GPR8. Proc Natl Acad Sci USA 100: 6251-6256, 2003.

7. Ishii M, Fei H and Friedman JM: Targeted disruption of GPR7, the endogenous receptor for neuropeptides $\mathrm{B}$ and $\mathrm{W}$, leads to metabolic defects and adult-onset obesity. Proc Natl Acad Sci USA 100: 10540-10545, 2003

8. Mondal MS, Yamaguchi H, Date Y, Shimbara T, Toshinai Y, Shimomura Y, Mori M and Nakazato M: A role for neuropeptide $\mathrm{W}$ in the regulation of feeding behavior. Endocrinology 144: 4729-4733, 2003.

9. Samson WK, Baker JR, Samson CK, Samson HW and Taylor MM: Central neuropeptide B administration activates stress hormone secretion and stimulates feeding in male rats. J Neuroendocrinol 16: 842-849, 2004.

10. Levine AS, Winsky-Sommerer R, Huitron-Resendiz S, Grace MK and De Lecea L: Injection of neuropeptide $\mathrm{W}$ into paraventricular nucleus of hypothalamus increases food intake. Am J Physiol 288: R1727-R1732, 2005.

11. Baker JR, Cardinal K, Bober C, Taylor MM and Samson WK: Neuropeptide $\mathrm{W}$ acts in brain to control prolactin, corticosterone, and growth hormone release. Endocrinology 144: 2816-2821, 2003.

12. Niimi $M$ and Murao K: Neuropeptide $\mathrm{W}$ as a stress mediator in the hypothalamus. Endocrine 27: 51-54, 2005.

13. Hochol A, Belloni AS, Rucinski M, Ziolkowska A, Di Liddo R, Nussdorfer GG and Malendowicz LK: Expression of neuropeptides $\mathrm{B}$ and $\mathrm{W}$ and their receptors in endocrine glands of the rat. Int J Mol Med 18: 1101-1106, 2006.

14. Hochol A, Albertin G, Nussdorfer GG, Spinazzi R, Ziolkowska A, Rucinski M and Malendowicz LK: Effects of neuropeptides B and $\mathrm{W}$ on the secretion and growth of rat adrenocortical cells. Int J Mol Med 14: 843-847, 2004.

15. Andreis PG, Rucinski M, Neri G, Conconi MT, Petrelli L, Parnigotto PP, Malendowicz LK and Nussdorfer GG: Neuropeptides $\mathrm{B}$ and $\mathrm{W}$ enhance the growth of human adrenocortical carcinoma-derived NCI-H295 cells by exerting MAPK p42/ p44-mediated proliferogenic and antiapoptotic effects. Int J Mol Med 16: 1021-1028, 2005

16. Mazzocchi G, Rebuffat P, Ziolkowska A, Malendowicz LK, Rossi GP and Nussdorfer GG: G protein receptors (GPR) 7 and 8 are expressed in human adrenocortical cells, and their endogenous ligands neuropeptides $\mathrm{B}$ and $\mathrm{W}$ enhance cortisol secretion by activating adenylate cyclase- and phospholipase C-dependent signaling cascades. J Clin Endocrinol Metab 90: 3466-3471, 2005

17. Rucinski M, Andreis PG, Ziolkowska A, Nussdorfer GG and Malendowicz LK: Differential expression and function of beacon in the rat adrenal cortex and medulla. Int J Mol Med 16: 35-40, 2005.

18. Lesniewska B, Miskowiak B, Nowak M and Malendowicz LK: Sex differences in adrenocortical structure and function. XXVII. The effect of stress on ACTH and corticosterone in intact, gonadectomized and testosterone- or estradiol-replaced rats. Res Exp Med 190: 95-103, 1990.

19. Rucinski M, Spinazzi R, Ziolkowska A, Nussdorfer GG and Malendowicz LK: Effects of beacon on the rat pituitaryadrenocortical axis response to stress. Int J Mol Med 16: 297-299, 2005.
20. Albertin G, Carraro G and Nussdorfer GG: Human adrenomedullin gene silencing by short interfering RNAs: a preliminary study. Int J Mol Med 15: 579-583, 2005.

21. Albertin G, Carraro G, Petrelli L, Guidolin D, Neri G and Nussdorfer GG: Endothelin-1 and adrenomedullin enhance the growth of human adrenocortical carcinoma-derived SW-13 cell line by stimulating proliferation and inhibiting apoptosis. Int $\mathbf{J}$ Mol Med 15: 469-474, 2005.

22. Albertin G, Rucinski M, Carraro G, Forneris M, Andreis PG, Malendowicz LK and Nussdorfer GG: Adrenomedullin and vascular endothelium growth factor genes are overexpressed in the regenerating rat adrenal cortex, and AM and VEGF reciprocally enhance their mRNA expression in cultured rat adrenocortical cells. Int J Mol Med 16: 431-435, 2005.

23. Rucinski M, Albertin G, Spinazzi R, Ziolkowska A, Nussdorfer GG and Malendowicz LK: Cerebellin in the rat adrenal gland: gene expression and the effects of CER and [des-Ser ${ }^{1}$ CER on the secretion and growth of cultured adrenocortical cells. Int J Mol Med 15: 411-415, 2005.

24. Rossi GP, Sticchi D, Giuliani L, Bernante P, Zavattiero S, Pessina AC and Nussdorfer GG: Adiponectin receptor expression in the human adrenal cortex and aldosterone-producing adenomas. Int J Mol Med 17: 975-980, 2006.

25. Ziolkowska A, Rucinski M, Di Liddo R, Nussdorfer GG and Malendowicz LK: Expression of the beacon gene in endocrine glands of the rat. Peptides 25: 133-137, 2004.

26. Belloni AS, Guidolin D, Salmaso R, Bova S, Rossi GP and Nussdorfer GG: Adrenomedullin, ANP and BNP are colocalized in a subset of endocrine cells in the rat heart. Int J Mol Med 15: 567-571, 2005.

27. Spinazzi R, Petrelli L, Guidolin D, Carraro G, Casale V, Tortorella C, Neri G, Albertin G, Andreis PG and Nussdorfer GG: In vitro culture on Matrigel favors the long-term maintenance of rat zona glomerulosa-cell differentiated phenotype. Int $\mathrm{J}$ Mol Med 17: 1101-1110, 2006.

28. Nussdorfer GG: Paracrine control of adrenal cortical function by medullary chromaffin cells. Pharmacol Rev 48: 495-530, 1996.

29. Conconi MT, Spinazzi R and Nussdorfer GG: Endogenous ligands of PACAP/VIP receptors in the autocrine-paracrine regulation of the adrenal gland. Int Rev Cytol 249: 1-51, 2006

30. Spinazzi R, Andreis PG and Nussdorfer GG: Neuropeptide-Y and $\mathrm{Y}$-receptors in the autocrine-paracrine regulation of adrenal gland under physiological and pathophysiological conditions (Review). Int J Mol Med 15: 3-13, 2005.

31. Nussdorfer GG and Malendowicz LK: Role of tachykinins in the regulation of the hypothalamo-pituitary-adrenal axis. Peptides 19: 949-968, 1998.

32. Nussdorfer GG, Rossi GP, Malendowicz LK and Mazzocchi G: Autocrine-paracrine endothelin system in the physiology and pathology of steroid-secreting tissues. Pharmacol Rev 51: 403-438, 1999.

33. Nussdorfer GG: Proadrenomedullin-derived peptides in the paracrine control of the hypothalamo-pituitary-adrenal axis. Int Rev Cytol 206: 249-284, 2001.

34. Mazzocchi G, Andreis PG, De Caro R, Aragona F, Gottardo L and Nussdorfer GG: Cerebellin enhances in vitro secretory activity of human adrenal gland. J Clin Endocrinol Metab 84 632-635, 1999.

35. Albertin G, Malendowicz LK, Macchi C, Markowska A and Nussdorfer GG: Cerebellin stimulates the secretory activity of the rat adrenal gland: in vitro and in vivo studies. Neuropeptides 34: 7-11, 2000.

36. Raha D, Tortorella C, Neri G, Prasad A, Raza B, Raskar R, Dubey R, Sen NS, Macchi C, Malendowicz LK, Ahmad MF and Nussdorfer GG: Atrial natriuretic peptide enhances cortisol secretion from guinea-pig adrenal gland: evidence for an indirect paracrine mechanism probably involving the local release of medullary catecholamines. Int J Mol Med 17: 633636,2006 